\title{
Process of Wear in the Lining of LD Pure-Oxygen Converters*
}

\author{
By Hiroshi Ohba** and Kiyoshi Sugita**
}

\section{Introduction}

It is vitally important for improvement in refractories and their proper operation to know the behaviors of the lining for steelmaking furnaces while in service and to have an exact idea of the process of wear. It is also necessary for attaining the accuracy of testing methods and the evaluation of quality of refractories to make investigations into the processes of wear. Any improvement and development of refractories for steelmaking furnaces should be based on a knowledge of this process of wear.

To learn the behavior of refractories while in service is actually a difficult problem, but of all the probable procedures, the examination of used refractories is one of the most correct and simple methods.

In Yawata Iron \& Steel Company, the LD converter process plant was placed into operation in September 1957, and the monthly production of LD steel amounts at present to approximately 220,000 m. tons.

The wear linings of converters of Yawata Steel are usually made with dolomite refractories, the service life of which is about 350 heats on an average, and 470 heats at the maximum.

Dolomite refractories are commonly classified according to their chemical and mineralogical compositions, and the type of bonding, as follows:

Chemical composition :

Semistable dolomite, containing a large amount of free $\mathrm{CaO}$.

Stable dolomite, containing only a small amount of free $\mathrm{CaO}$ (not more than $1.0 \%$ ).

Bonding type :

Tar-bonded or organic-bonded.

Chemically bonded or cement-bonded.

Ceramic-bonded or crystalline-bonded.

The two kinds of dolomite refractories are now in use at Yawata Works; the semistable tar-bonded dolomite bricks and burnt dolomite bricks which are stabilized and ceramic-bonded. The word 'stable' here does not mean a stability or resistance of bricks to corrosion or slagging, but to hydration.

The present paper deals with the results of in- vestigation in September, 1958 of the abovementioned two kinds of dolomite bricks taken from No. 1 converter (nominal capacity 50 tons) at Kukioka Plant of Yawata Steel in which samples were examined for processes of wear during service after they had been used.

\section{Properties of Dolomite Bricks as Supplied}

In Table 1 are shown the properties of dolomite bricks before they were used. The tar-bonded bricks were manufactured by moulding a mixture of semistable dolomite grains, magnesia grains and coal tar as binder; the burnt bricks were made by burning the moulded mixture of $\mathrm{SiO}_{2}$-stabilized dolomite grains and magnesia grains.

\section{Sampling of Used Bricks}

The 22 pieces of used bricks were taken as samples from various positions of the lining of the barrel and the bottom of No. 1 converter, and used in the examination. It was inferred as the result that the wear of bricks in these two parts was different according to their positions but their processes of wear were the same with regard to the same kind of bricks. It was presumed that the kind of brick caused the difference in the process of wear.

Accordingly a more minute examination was carried out with two used bricks, a tar-bonded dolomite brick taken from the 4th tier above the bottom and, the other a burnt dolomite brick from the 12th tier as shown in Fig. 1. In Fig. 2 are shown the appearances of the two samples after they were used.

\section{Experimental Results of the Used Tar- Bonded Brick}

\section{Appearance and Mechanical Strength}

The hot side of the brick was of slightly fused rough face, and almost no cracks or fissures were observed inside of the brick, nor was there any brittleness due to oxidation of the tar-bond. Its cold crushing strength was 140 to $200 \mathrm{~kg} / \mathrm{cm}^{2}$ in

Table 1. Properties of dolomite bricks before service in LD converters

\begin{tabular}{|c|c|c|c|c|c|c|c|c|c|c|}
\hline \multirow{2}{*}{$\begin{array}{l}\text { Properties } \\
\text { Bricks }\end{array}$} & \multirow{2}{*}{$\begin{array}{l}\text { Bulk density } \\
\qquad\left(\mathrm{g} / \mathrm{cm}^{3}\right)\end{array}$} & \multirow{2}{*}{$\begin{array}{l}\text { Crushing } \\
\text { strength } \\
\left(\mathrm{kg} / \mathrm{cm}^{2}\right)\end{array}$} & \multirow{2}{*}{$\begin{array}{l}\text { Refractoriness-under-load }{ }^{*} \\
\left({ }^{\circ} \mathrm{C}\right)\end{array}$} & \multicolumn{6}{|c|}{ Chemical composition $(\%)$} & \multirow{2}{*}{$\begin{array}{l}\text { Mineralogical } \\
\text { constitution }\end{array}$} \\
\hline & & & & $\begin{array}{l}\text { Ig. } \\
\text { loss }\end{array}$ & $\mathrm{SiO}_{2}$ & $\mathrm{Al}_{2} \mathrm{O}_{3}$ & $\mathrm{Fe}_{2} \mathrm{O}_{3}$ & $\mathrm{CaO}$ & $\mathrm{MgO}$ & \\
\hline Tar-bonded & 2.88 & 415 & 1580 & 4.71 & 3.63 & 1.19 & 2.02 & 32.67 & 54.26 & $\begin{array}{l}\text { Periclase }+ \\
\text { free CaO }\end{array}$ \\
\hline Burnt & 2.77 & 555 & 1640 & 0.54 & 10.44 & 1.21 & 2.44 & 38.64 & 45.61 & $\begin{array}{l}\text { Periclase }+ \\
3 \mathrm{CaO} \cdot \mathrm{SiO}_{2}\end{array}$ \\
\hline
\end{tabular}

* Initial softening point under a load of $2 \mathrm{~kg} / \mathrm{cm}^{2}$.

* Lecture delivered before the 61st Grand Lecture Meeting of the Iron \& Steel Institute of Japan on April 5th, 1961 in Tokyo. Japanese text was printed in “'Tetsu-to-Hagané” (Journal, Iron \& Steel Institute, Japan) Vol. 47, No. 3, pp. 343-345.

** Engineers, Technical Research Institute of Yawata Works, Yawata Iron \& Steel Co., Ltd. 


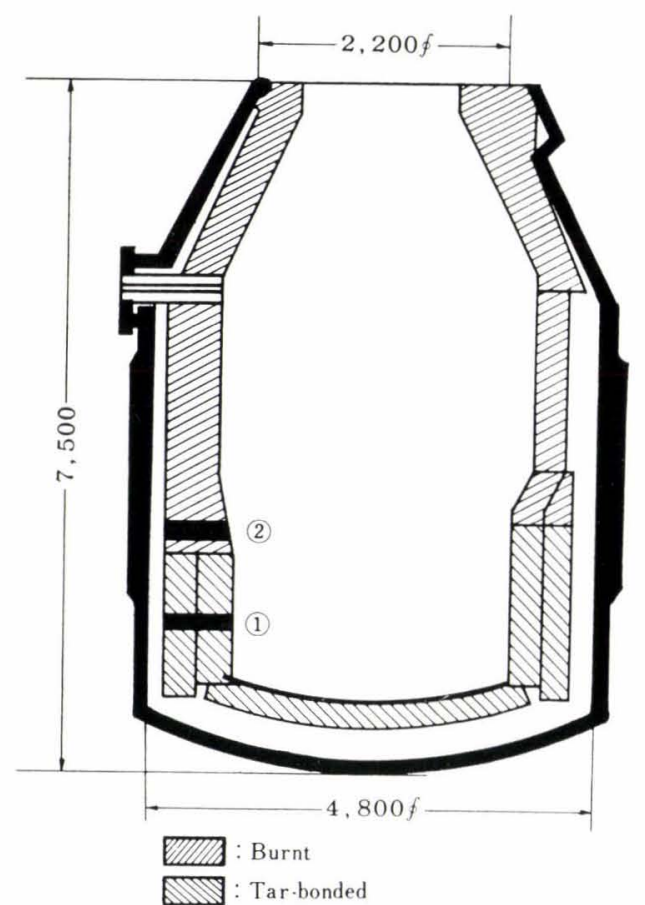

Fig. 1. Cross section of the oxygen converter, showing the position of sampled bricks for detailed examination

(1) Tar-bonded dolomite brick sampled

(2) Burnt dolomite brick sampled
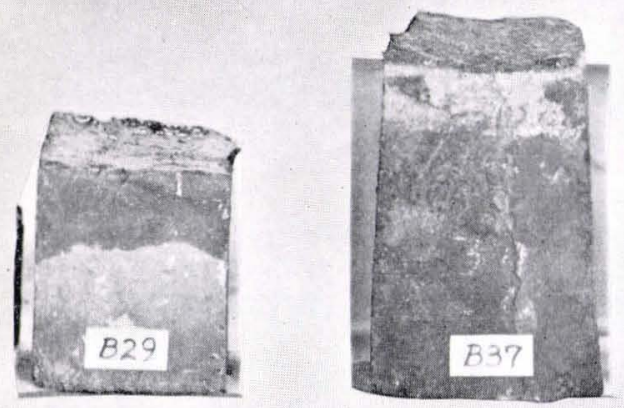

Fig. 2. Appearance of used dolomite bricks (left : burnt, right: tar-bonded the portion adjacent to the hot face and 180 to 640 $\mathrm{kg} / \mathrm{cm}^{2}$ near the back face.

The refractoriness-under-load, which could indicate, in a sense, the hot strength was above $1620^{\circ} \mathrm{C}$ in the initial deforming point and above $1700^{\circ} \mathrm{C}$ in the $2 \%$ deforming point, in both portions adjacent to the hot face.

\section{Microstructures, Chemical and Mineralogical Con- stitutions}

Remarkable changes in the microstructures, and in the chemical and mineralogical constitutions were found only in the portion adjacent to the hot face of the used brick.

The constitution of the zones in the used brick can be typically illustrated in Fig. 3. The following three zones were found in the brick:

Fluxed zone: This zone, extending from the hot face for about $1 \mathrm{~mm}$ into the brick, consists of the products of reaction between refractory materials and various oxides from the charge, especially the basic slag, in the converter.

Decarburized zone: This is the second zone of about $1 \mathrm{~mm}$ in thickness, where the tar-bond has been completely oxidized and disappeared and the ceramic bond is formed, resulting from its sintering in service.

Tar-bonded zone: This zone, lying behind the decarburized zone, is tar-bonded. The tar-bond remains almost unchanged.

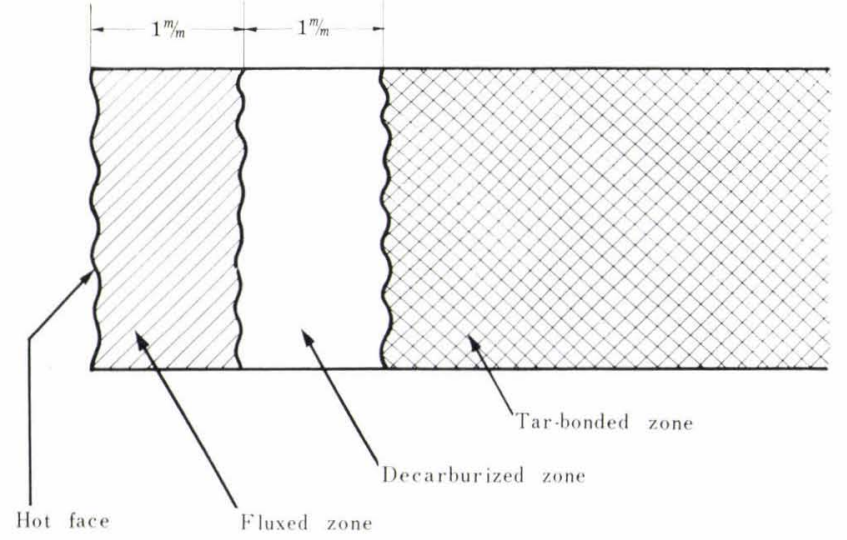

Fig. 3. Illustration of zoning in a tar-bonded dolomite brick after service

Table 2. Chemical composition of the used tar-bonded dolomite brick

\begin{tabular}{|c|c|c|c|c|c|c|c|}
\hline Zone $\quad$ Composition (wt \%) & $\begin{array}{c}\text { Ig. } \\
\text { loss }\end{array}$ & $\mathrm{SiO}_{2}$ & $\mathrm{Al}_{2} \mathrm{O}_{3}$ & $\mathrm{Fe}_{2} \mathrm{O}_{3}$ & $\mathrm{MnO}$ & $\mathrm{CaO}$ & $\mathrm{MgO}$ \\
\hline Fluxed + decarburized ${ }^{* *}$ & 0.12 & 5.90 & 3.87 & 9.92 & 6.32 & 34.99 & 35.05 \\
\hline $40 \mathrm{~mm}$ & $12.25^{*}$ & 2.74 & 1.00 & 3.15 & 1.91 & 33.88 & 43.70 \\
\hline $100 \mathrm{~mm}$ & $13.48^{*}$ & 2.40 & 0.99 & 1.56 & 2.42 & 31.64 & 47.61 \\
\hline
\end{tabular}

* Including the hydrated water after sampling.

** $1.38 \%$ of $\mathrm{P}_{2} \mathrm{O}_{5}$ detected. 
The chemical analysis of the used brick, as is given in Table 2, shows that the content of the fluxing components such as iron-oxide, $\mathrm{Al}_{2} \mathrm{O}_{3}, \mathrm{SiO}_{2}$ increased in the fluxed and decarburized zones, but that the chemical composition of the tar-bonded zone remains similar to that of the unused brick.

In the portion adjacent to the hot face, remarkable changes in the mineralogical composition were also observed, although some degree of sintering and crystal-growth in periclase and lime had taken place in the area adjacent to the tar-bonded zone.

Mineralogical observation and X-ray analysis show that periclase $(\mathrm{MgO})$, dicalcium-silicate $(\gamma$ $\left.2 \mathrm{CaO} \cdot \mathrm{SiO}_{2}\right)$, monocalcium-ferrite $\left(\mathrm{CaO} \cdot \mathrm{Fe}_{2} \mathrm{O}_{3}\right)$, and magnesio-ferrite $\left(\mathrm{MgO} \cdot \mathrm{Fe}_{2} \mathrm{O}_{3}\right)$ have been formed in the fluxed zone.

The crystals of periclase are yellow or brown colored, due to forming solid solutions with $\mathrm{MgO} \cdot \mathrm{Fe}_{2} \mathrm{O}$ and $\mathrm{FeO}$. A considerable amount of dicalcium-ferrite $\left(2 \mathrm{CaO} \cdot \mathrm{Fe}_{2} \mathrm{O}_{3}\right)$ was also detected in a dolomite grain in the hot face.

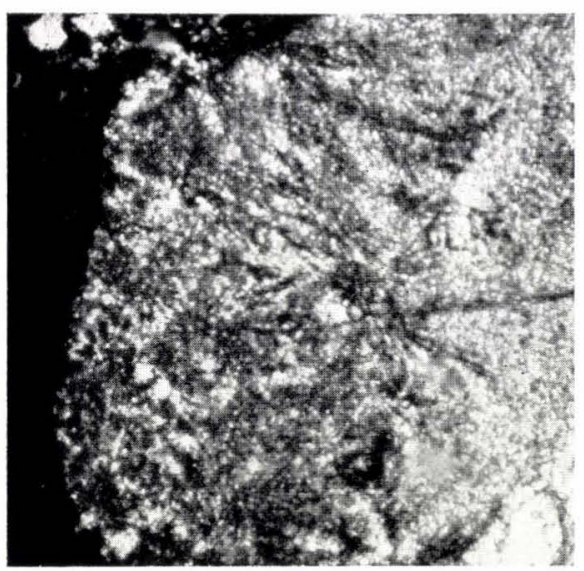

Fig. 4. Dolomite grain on the hot face after lise (open Nicols $\times 75$, iron-oxide penetrating into the grain in a needle-like form. Hot face is on the left.)
Fig. 4 shows the microstructure of a dolomite grain in the fluxed and decarburized zones, where iron-oxide had penetrated into the dolomite grain in a needle-like form, producing $2 \mathrm{CaO} \cdot \mathrm{Fe}_{2} \mathrm{O}_{3}$.

\section{Experimental Results of Used Burnt Dolo- mite Bricks}

\section{Appearance and Degree of Sintering}

Cracks and microfissures were observed in the used brick, parallel with and at the distance of 80 to $110 \mathrm{~mm}$ inside the hot face. The hot face presents a smooth surface covered with fluxed material. The portion adjacent to the hot face had been finely sintered, the porosity of which is 8 to $10 \%$ at a distance of 10 to $20 \mathrm{~mm}$ from the hot face. This is about one half of the original porosity $(15-20 \%)$.

\section{Chemical Composition}

The chemical composition of the used brick differs remarkably according to the distance from the surface of the hot face, which indicates migration or penetration of various components of the hot face into the inside of the brick during service. Table 3 shows the chemical analysis of the used bricks classified according to the distance from the hot face.

\section{Mineralogical Constitution and Microstructures}

The minerals, detected by microscopic observation and X-ray analysis, are periclase $(\mathrm{MgO})$, magnesio-ferrite $\left(\mathrm{MgO} \cdot \mathrm{Fe}_{2} \mathrm{O}_{3}\right)$, monocalcium-ferrite $\left(\mathrm{CaO} \cdot \mathrm{Fe}_{2} \mathrm{O}_{3}\right)$. Periclase grains are stained black, forming solid solutions with magnesio-ferrite and ferrous oxide. The mineralogical constitution varies according to the change in the chemical composition of the brick.

Especially in the portion at a distance of 80 to $110 \mathrm{~mm}$ from the surface of the hot face, where cracks and fissures formed and brittle structure was detected, a considerable amount of free $\mathrm{CaO}$

Table 3. Chemical composition of the used burnt dolomite brick

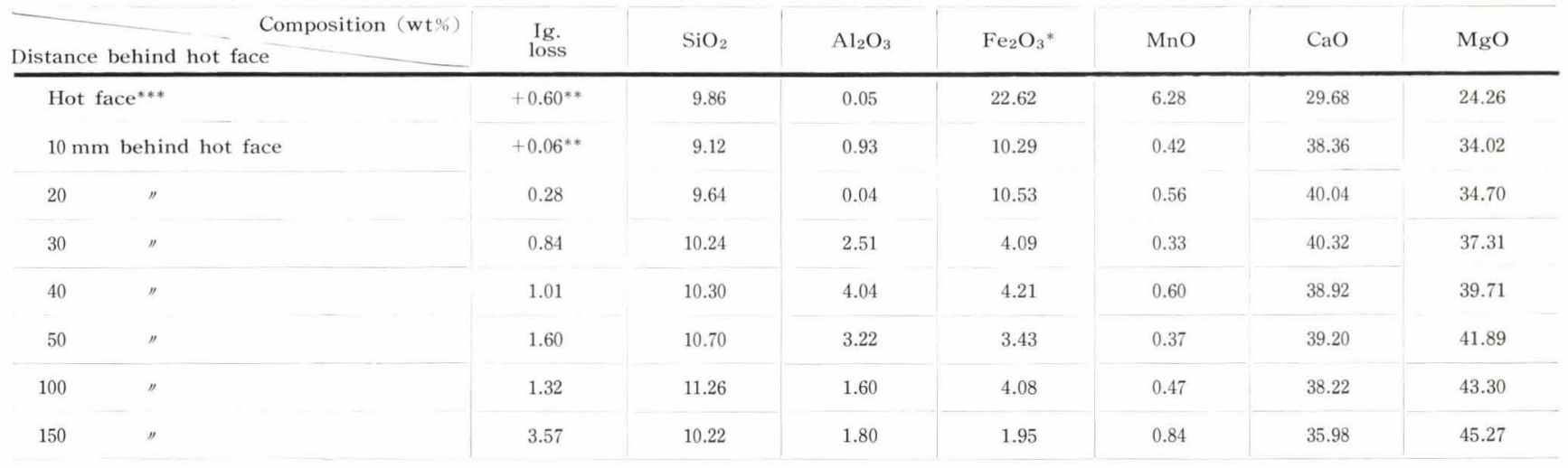

* All the iron oxides are designated in the form of $\mathrm{Fe}_{2} \mathrm{O}_{3}$.

** Weight increased when ignited.

*** $1.18 \%$ of $\mathrm{P}_{2} \mathrm{O}_{5}$ detected. 
was detected by White's Test ${ }^{1)}$. Therefore, the determination of free $\mathrm{CaO}$ in the brick was carried out to find out the relationship between the distance from the hot face and the existence of free $\mathrm{CaO}$ in the brick by the improved ammonium-acetate method. As the result, it was found that there is a good coincidence between the distances of maximum concentration of free $\mathrm{CaO}$ and the occurrence of cracks or fissures, as is shown in Table 4. The origin of this free $\mathrm{CaO}$ is, as described later, from tricalcium-silicate in the brick.

Table 4. Free $\mathrm{CaO}$ contents along with distance behind the hot face in the used burnt dolomite brick

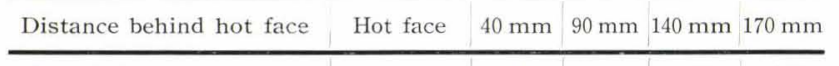

\begin{tabular}{|l|l|l|l|l|l|}
\hline Free $\mathrm{CaO}$ in \% & 0.38 & 1.50 & 1.78 & 1.55 & 0.63
\end{tabular}

\section{Discussion on Processes of Wear}

\section{Tar-Bonded Dolomite Bricks}

One of the characteristic service behaviors of tar-bonded dolomite bricks suggested by the results above lies in the fact that, notwithstanding their nature of basic refractories, the flux penetration does not take place in the deeper portion of the bricks, but only in the neighboring part of the hot face. This may be explained to have been caused by the tar-bond in the brick. In other words, the brick contains carbonaceous materials originated from the tar-bond, which will retard the migration of flux, because carbon does not "wet" well with fluxes such as basic slags that will penetrate into the structure of bricks in molten state.

From these results it was also inferred that the decarburized zone is too thin to cause occurrence of flaking in this zone. It has long been assumed that the wear of tar-bonded dolomite bricks during service occurs with flaking from the brittle decarburized zone where the binding strength of tar is lost due to oxidation. The results of investigation this time, however, confirmed that the decarburized zone does not cause flaking because of its being so thin (about $1 \mathrm{~mm}$ ) and of its forming a firm ceramic-bond-structure.

Therefore, the process of wear of tar-bonded dolomite bricks in oxygen-converter linings can be explained as follows:

The tar-bond at about $2 \mathrm{~mm}$ of the hot face is oxidized and disappears and at the same time various components, mainly consisting of iron-oxide, $\mathrm{SiO}_{2}$, will migrate into the decarburized portion to react with the dolomite refractory forming the fluxed zone, and some portion remaining as a decarburized zone. The contents of flux such as ironoxide, $\mathrm{SiO}_{2}, \mathrm{Al}_{2} \mathrm{O}_{3}$ increase gradually and lower the refractoriness of the fluxed zone, that is to lower its hot viscosity. The fluxed zone, forming the hot face, will be abraded away into the furnace with molten metal and slag, at the time when the flux content has increased to a certain amount, or when the hot viscosity of the hot face has reached a certain value.

The total content of fluxes in the fluxed zone of this sample $\left(\mathrm{Fe}_{2} \mathrm{O}_{3}+\mathrm{Al}_{2} \mathrm{O}_{3}+\mathrm{SiO}_{2}+\mathrm{MnO}\right)$ amounts to about $25 \%$. The total content of fluxes presumably ranges from 20 to $40 \%$, depending upon the position of the brisk in the lining, under service in oxygen converters. Thus the wear of bricks proceeds continuously, forming a new fluxed zone, a new decarburized zone in the portion adjoining to the hot face.

The decarburized zone is, as mentioned before, so thin that presumably it is saturated with fluxes in a comparatively short time. Therefore, the rate of wear is determined by the forming rate of the decarburized zone in the tar-bonded dolomite bricks.

The process of wear of the tar-bonded dolomite bricks in the barrel and the bottom linings of oxygen converters is mentioned above, but the rate of wear appears to vary to some extent, depending on the position of the bricks in the lining. The same thing that occurs in the case of burnt dolomite bricks will be described next. The process of wear itself, however, may be thought to be the same with any position of the barrel or the bottom of converters.

\section{Burnt Dolomite Bricks}

Contrary to the case of tar-bonded dolomite bricks, in burnt dolomite bricks fluxes were found to have penetrated far deeper inside of bricks during service. This is the chief feature in the burnt dolomite bricks used.

Fig. 5 shows the distribution of fluxes along the distances from the hot face of the brick figured out from the results given in Table 3 , where the absissa is scaled with the distance and the ordinate with relative weight ratio of each component to $\mathrm{MgO}$.

The reason why the relative ratio to $\mathrm{MgO}$ is used is that $\mathrm{MgO}$ is the component with the least probability to migrate or penetrate at temperatures during service.

Fig. 5, showing the distribution of concentration of each component, confirms that the brick has absorbed such components as iron-oxide, $\mathrm{SiO}_{2}, \mathrm{CaO}$, $\mathrm{Al}_{2} \mathrm{O}_{3}$ into the portion inside of the brick, and that the distribution behavior is characteristic of each component. (Fluxes have penetrated about $100 \mathrm{~mm}$ into the brick.)

The maximum concentration of $\mathrm{Al}_{2} \mathrm{O}_{3}$ at the distance of $30 \mathrm{~mm}$ from the hot face is caused mainly by the temperature distribution in the brick.

Tricalcium-silicate $\left(3 \mathrm{CaO} \cdot \mathrm{SiO}_{2}\right)$, one of the main 


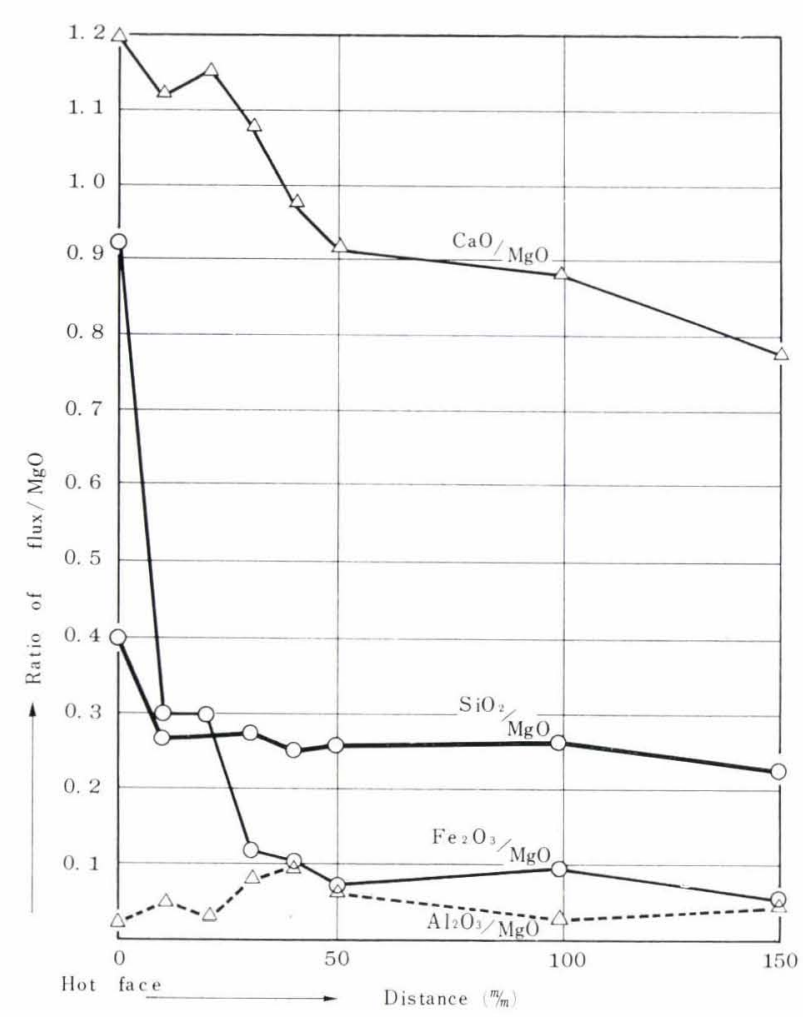

Fig. 5. Distribution of absorbed components along with distance behind the hot face in the burnt dolomite brick after 316 heats service

constitutional minerals in the burnt dolomite brick, decomposes at about $1200^{\circ} \mathrm{C}$ to produce free $\mathrm{CaO}^{2}$ ) as follows:

$$
3 \mathrm{CaO} \cdot \mathrm{SiO}_{2} \longrightarrow 2 \mathrm{CaO} \cdot \mathrm{SiO}_{2}+\mathrm{CaO}
$$

A good coincidence was found between the distance of crack formation and of maximum concentration of free $\mathrm{CaO}$. The decomposition cited above will take place, when some portion of the brick is kept at about $1200^{\circ} \mathrm{C}$ for a long period during service. This decomposition, causing microstructures of the brick to become brittle, will accelerate to develop cracks and fissures in this portion with mechanical or thermal shocks. Anyway the decomposition of tricalcium-silicates will have an intimate connection with the crack formation, sometimes resulting in flaking of the brick in service.

The process of wear of burnt dolomite bricks is, as a result, explained as follows:

The hot face is abraded away, when the hot viscosity of the hot face has reached a certain value, resulting from the increase in flux contents. The total content of fluxes $\left(\mathrm{Fe}_{2} \mathrm{O}_{3}+\mathrm{Al}_{2} \mathrm{O}_{3}+\mathrm{SiO}_{2}+\mathrm{MnO}\right)$ amounts to about $25 \%$ at the time of abrasion in this sample. The critical content of fluxes, although depending on the position of the brick in the furnace, is supposed to range from 20 to $40 \%$, similar to the case of tar-bonded dolomite bricks.
The rate-determining step of wear of the burnt dolomite brick will be, unlike that of the tar-bonded one, the rate of absorption or migration of various components from the hot face, which is affected not only by the chemical and mineralogical constitution of the brick, but also by the size and distribution of pores and the temperature distribution in the brick. In addition to the processes explained above, the flaking, caused by the crack formation in the brick must be noted as a subordinate process of wear. Here, the decomposition of tricalcium-silicate will play a significant role as one of the processes of crack formation.

\section{Corrosion Resistance of Dolomite Refractories}

The results of this investigation on the used bricks reveal that the process of wear of dolomite refractories in oxygen converter linings can be investigated as a problem of hot chemical reactions within the system of $\mathrm{MgO}-\mathrm{CaO}-\mathrm{Fe}_{2} \mathrm{O}_{3}-\mathrm{SiO}_{2}-\mathrm{Al}_{2} \mathrm{O}_{3}$ $\mathrm{MnO}$. Iron oxides may have the strongest fluxing action on the oxygen converter linings among the various flux components.

This is proved by the fact that there are detected a large amount of ferrite-minerals, such as $\mathrm{MgO}$. $\mathrm{Fe}_{2} \mathrm{O}_{3}, \mathrm{CaO} \cdot \mathrm{FeO}_{3}, 2 \mathrm{CaO} \cdot \mathrm{Fe}_{2} \mathrm{O}_{3}$ in the hot face of used dolomite bricks. It seems proper, therefore, to investigate the corrosion resistance of dolomite refractories for oxygen converter linings as a hot reaction in the system $\mathrm{MgO}-\mathrm{CaO}-\mathrm{Fe}$ oxide, like the experiments by J. White and W. F. Ford.

The main constitutional minerals in dolomite refractories, including stable and semistable dolomite, are periclase $(\mathrm{MgO})$, free $\mathrm{CaO}$, tricalciumsilicate $\left(3 \mathrm{CaO} \cdot \mathrm{SiO}_{2}\right)$ and dicalcium-silicate $(2 \mathrm{CaO}$. $\mathrm{SiO}_{2}$ ).

The decreasing order of corrosion resistance, especially against iron-oxide, of these minerals as a component of bricks can be described as follows:

$\mathrm{MgO}>\mathrm{CaO}>3 \mathrm{CaO} \cdot \mathrm{SiO}_{2}>2 \mathrm{CaO} \cdot \mathrm{SiO}_{2}$

In the case of bricks equal in the content of $\mathrm{MgO}$, therefore, the corrosion resistance is decreased with the degree of stability or increased with the content of free $\mathrm{CaO}$. The content of free $\mathrm{MgO}$ and free $\mathrm{CaO}$ in the brick may be used as an index to evaluate its corrosion resistance.

According to the rule given above, it follows that tar-bonded dolomite bricks (semistable dolomite) are preferable to burnt dolomite bricks (stable dolomite).

In actual practice, however, the bricks must have higher mechanical strength and higher resistance against hydration, in addition to the abovementioned chemical compositions. Especially in such a country as Japan where humidity is much higher than in other countries, care must be taken against the hydration of semistable dolomite bricks. 
It is presupposed that, as a future trend in dolomite bricks for oxygen converter linings, a superiority of semistable dolomite refractories (particularly tar-bonded dolomite bricks) will be recognized.

The present investigation also suggests that the effect of carbon in the tar-bond is an important problem for tar-bonded dolomite refractories.

It must be added here that, concerning the effect of carbon in tar-bonded dolomite refractories, P. Metz has already released excellent opinions about the lining of bottom-blown converters.

\section{Summary}

Examining the two kinds of dolomite bricks that were used in the lining of oxygen converters of Yawata Iron \& Steel Company, the processes of wear at the barrel and the bottom of the furnace were discussed and presumed from the results obtained. These results, it is considered, can be applied to an improvement in refractories hereafter, and also can be used as a guide for better service in future.

The following is the summary of the results:

(1) The wear of dolomite bricks for oxygen converter linings can be studied as a hot chemical reaction in the system $\mathrm{MgO}-\mathrm{CaO}-\left(\mathrm{Fe}\right.$ oxide) $-\mathrm{SiO}_{2}$ $\mathrm{Al}_{2} \mathrm{O}_{3}-\mathrm{MnO}$. It is desirable that this problem is investigated in the system $\mathrm{MgO}-\mathrm{CaO}$-( Fe oxide), because iron oxides have the strongest fluxing effects on the wear of linings.

(2) The wear of tar-bonded dolomite bricks takes place when refractoriness of the hot face is lowered due to the reaction of the components in the furnace. The wear rate is determined by the forming rate of the decarburized zone.

(3) The wear of burnt dolomite bricks takes place in a similar way owing to the lowering of refractoriness of the hot face that is to be caused by the reaction of the components in the furnace. The rate-determining step of wear, however, is estimated to be the rate of absorption of various components from the hot face into the inside of the brick.

(4) As a future trend in dolomite bricks for oxygen converter linings, superiority of semistable dolomite refractories, especially, tar-bonded one is expected.

\section{REFERENCES}

1) G. R. Rigby: The Thin-Section Mineralogy of Ceramic Materials, (1953) p. 219, Brit. Cer. Res. Assoc.

2) E. T. Carlson: Bur. Standards J. Res., 7 (1931), 5, pp. 893-902.

3) W. F. Ford \& J. White: Refractories J., (1958) 4, pp. 171-174.

4) P. Metz: Stahl u. Eisen, 74 (1954), ss. 10-24. 